\title{
Comparison of epidural and intravenous route for acute and chronic postoperative pain control in patients with gynecological malignancy
}

\author{
Jinekolojik maligniteli hastalarda akut ve kronik postoperatif ağrı için epidural ve \\ intravenöz yolun karşılaştırılması
}

\section{Bedih BALKAN, 1 (D) Gökhan DEMIRAYAK, ${ }^{2}$ (D) Halil ÇETINGÖK, ${ }^{3}$ (D) Cihan COMBA, ${ }^{2}$ (D) Yusuf Ziya YENER, Gülsüm Oya HERGÜNSEL,' $($ isa Aykut ÖZDEMIR²}

\section{Summary}

Objectives: This study compared the effects of patient-controlled epidural and intravenous analgesia on acute and chronic postoperative pain in patients who were operated on for gynecological malignancy.

Methods: Postoperatively, patient-controlled analgesia was administered via epidural route to Group 1 and the intravenous route to Group 2. Pain was evaluated using the Visual Analog Scale (VAS) in the acute phase at postoperative 24 hours and at 6 months in the chronic phase.

Results: The VAS scores at 24 hours were lower in Group 1 than in Group 2 ( 3.29 vs 3.93; $p<0.05$ ). The VAS scores at 6 months were 2.03 in Group 1 and 2.53 in Group 2, indicating no statistically significant difference $(p>0.05)$. There was no significant difference in the Leeds Assessment of Neuropathic Symptoms and Signs pain scale scores at 6 months ( $p>0.05$ ).

Conclusion: The results showed that epidural and intravenous analgesia had a similar effect regarding the chronicity of pain but better outcomes were achieved with epidural analgesia in the acute stage.

Keywords: Acute postoperative pain; chronic postoperative pain; epidural patient-controlled analgesia; gynecologic malignancy; intravenous patient-controlled analgesia.

\begin{abstract}
Özet
Amaç: Jinekolojik malignite nedeniyle ameliyat edilen hastalarda epidural veya intravenöz hasta kontrollü analjezinin akut ve kronik postoperatif ağrı üzerine etkisini karşılaştırmak.

Gereç ve Yöntem: Postoperatif hasta kontrollü analjezi Grup 1 için epidural yol ve Grup 2 için intravenöz yoldan uygulandı. Ağrı, akut fazda postoperatif 24. saat ve kronik fazda 6. ayda Vizüel Analog Skoru (VAS) kullanılarak değerlendirildi.

Bulgular: 24. saatte VAS skoru Grup 1'de Grup 2'ye göre daha düşük bulundu (3.29 ve 3.93; $p<0.05$ ). Altıncı aydaki VAS skorları istatistiksel anlamlı farklılık göstermeyecek şekilde Grup 1'de 2.03 ve Grup 2'de 2.53 idi. Altıcı aydaki LANSS skorlarında da anlamlı farklılık yoktu $(\mathrm{p}>0.05)$.

Sonuç: Bizim sonuçlarımız, akut dönemde epidural analjezi ile daha iyi sonuçlar elde edilebilmesine rağmen epidural ve intravenöz analjezinin ağrının kronikliği için benzer etkilere sahip olduğunu gösterdi.

Anahtar sözcükler: Akut postoperatif ağrl; kronik postoperatif ağrl; epidural hasta kontrollü analjezi; jinekolojik malignite; intravenöz hasta kontrollü analjezi.
\end{abstract}

\section{Introduction}

The incidence of gynecological malignancies has been increasingly recognized. According to the US National Cancer Institute, more than 100.000 individuals have been newly diagnosed with a gyneco- logical malignancy. ${ }^{[1]}$ In parallel to increased number of patients, the number of oncological surgeries has been arising. Compared to traditional open surgical procedures, minimally invasive surgery has led to decreased postoperative pain in patients with gyne-

\footnotetext{
'Department of Anesthesiology and Reanimation, Bakırköy Dr. Sadi Konuk Training and Research Hospital, İstanbul, Turkey 2Department of Gynecologic Oncology, Bakırköy Dr. Sadi Konuk Training and Research Hospital, İstanbul, Turkey ${ }^{3}$ Division of Algology, Department of Anesthesiology and Reanimation, İstanbul University Faculty of Medicine, İstanbul, Turkey Submitted (Başvuru tarihi) 13.07.2019 Accepted after revision (Düzeltme sonrası kabul tarihi) 18.11.2019 Available online date (Online yayımlanma tarihi) 27.03.2020

Correspondence: Dr. Gökhan Demirayak. Bakırköy Dr. Sadi Konuk Eğitim ve Araştırma Hastanesi, Jinekolojik Onkoloji Kliniği, İstanbul, Turkey. Phone: +90 -212 - 4147171 e-mail:dmryk.g@gmail.com

(c) 2020 Turkish Society of Algology
} 
cologic cancer. ${ }^{[2,3]}$ However, minimally invasive approach is not technically feasible in some patients with gynecologic malignancy. When compare with minimal invasive approach, the patients who had a laparotomy for gynecologic malignancy tended to require significantly more narcotic and non-narcotic analgesics. ${ }^{[4]}$ Postoperative pain is still a major problem. [5] $4.7-26.2 \%$ of patients underwent hysterectomy for benign condition experience chronic postoperative pain. ${ }^{[6]}$ In addition, the disease itself and postoperative chemotherapy complicate the management of chronic postoperative pain in this patient population.

Surgery-related acute postoperative pain is an important, but modifiable risk factor for chronic postoperative pain. ${ }^{[7]}$ Two analgesia methods are used to prevent acute postoperative pain: multimodal analgesia and preemptive analgesia. ${ }^{[8]}$ Preemptive analgesia is an anti-nociceptive treatment which is initiated before surgery. Previous studies have demonstrated that surgical stimuli increase the excitability of dorsal horn neurons and avoidance of such a scenario reduces postoperative hyperalgesia. ${ }^{[9]}$ Multimodal analgesia is a pharmacological method of pain management. It involves the administration of two or more analgesic agents, which exert their effects via different analgesic mechanisms, or procedures (i.e., peripheral nerve blocks). ${ }^{[10]}$ Although there are a few studies that compared epidural and IV patient-controlled analgesia for postoperative pain control of patients with gynecologic malignancy for acute period, ${ }^{[11-13]}$ there are no study for chronic period.

In the present study, we aimed to compare the effects of epidural patient-controlled analgesia or intravenous (IV) patient-controlled analgesia with tramadol on acute and chronic postoperative pain (nociceptive-neuropathic) in patients who were operated through midline incision for gynecological malignancy

\section{Material and Methods}

\section{Study population}

This study was conducted at Health Sciences University of Turkey, Bakırköy Dr. Sadi Konuk Training and Research Hospital between January 2017 and July 2017. A total of 122 women who underwent gynecologic oncology surgery due to primary en- dometrial or ovarian carcinoma were retrospectively evaluated. The inclusion criteria followed: (a) vertical midline incision, (b) staging surgery included para-aortic lymphadenectomy up to the left renal vein or primary debulking surgery for primary endometrial or ovarian/fallopian tube/primary peritoneal carcinoma, (c) ASA class I-III. Exclusion criteria included the following: (a) laparoscopic surgery, (b) known allergy to the study drugs, (c) ASA Class IV-V, (d) neurological disorders such as myotonia, myasthenia gravis, and Lambert-Eaton syndrome, (e) severe cardiac arrhythmia (i.e., atrioventricular block), using monoamine oxidase inhibitors, and (f) known alcohol or opioid dependence.

The patients were divided into two groups with regard to analgesia regimes. Group 1 received epidural patient-controlled analgesia with bupivacaine and fentanyl and Group 2 received IV patient-controlled analgesia with tramadol.

\section{Perioperative management}

In the operating room, all patients underwent electrocardiography and $\mathrm{SpO}_{2}$ and non-invasive arterial blood pressure were monitored using Datex Engstrom (Datex Ohmeda, Helsinki, Finland). The IV access was maintained using a $20 \mathrm{G}$ cannula through the antecubital vein. All patients received preemptive analgesia with tramadol $100 \mathrm{mg}$ and paracetamol $1000 \mathrm{mg}$ preoperatively through IV route and pain control was maintained with remifentanil infusion during surgery. Before anesthesia induction, balanced solution $(4 \mathrm{~mL} / \mathrm{kg}$ ) was administered. Sedation was given with midazolam (Dormicum ${ }^{\circledR}$, Roche) $0.03 \mathrm{mg} / \mathrm{kg}$ and fentanyl $1 \mu \mathrm{g} / \mathrm{kg}$ (Fentanyl Citrate, Roche). For anesthesia induction, propofol 1-2 mg/ $\mathrm{kg}$, remifentanil (Ultiva ${ }^{\circledR}$, GlaxoSmithKline) $0.5 \mu \mathrm{g} / \mathrm{kg}$, and rocuronium bromide $0.6-1 \mathrm{mg} / \mathrm{kg}$ were used. Following orotracheal intubation, anesthesia maintenance was achieved with sevoflurane MAC 0.8-1 and remifentanil $0.0625-0.25 \mu \mathrm{g} / \mathrm{kg} / \mathrm{min}$.

In Group 1, a thoracic epidural catheter was placed in the lateral decubitis position using an 18G Tuohy needle (Perifix $701 \mathrm{G}$ soft type-Braun) and postoperative epidural patient-controlled analgesia was maintained with bupivacaine $125 \mathrm{mg}$ and fentanyl $0.2 \mathrm{mg}$ in $100 \mathrm{~mL} 0.9 \% \mathrm{NaCl}$ solution (baseline rate: $1 \mathrm{~mL}$; on-demand dose: $2 \mathrm{~mL}$; lockout time: $20 \mathrm{~min}$ ). 
In Group 2, an IV patient-controlled analgesia pump was fitted postoperatively through tramadol $400 \mathrm{mg}$ in $100 \mathrm{~mL} 0.9 \% \mathrm{NaCl}$ solution (baseline rate: $10 \mathrm{mg}$; on-demand dose: $10 \mathrm{mg}$; lockout time: $12 \mathrm{~min}$ ).

Data collection

In this retrospective cohort study, demographic data including age, BMl, comorbidities and clinical data including operative procedures, estimated blood loss, need for blood transfusion, complications, radiation therapy/chemotherapy applied and the Visual Analog Scale (VAS) for pain at $24 \mathrm{~h}$ were obtained from the electronical medical records of the patients. In the VAS graded from 0 (no pain) to 10 (the worst possible pain) daily.

VAS evaluated postoperatively at least 6 months through face-to-face interviews for chronic phase by a gynecologic oncology fellow. A written informed consent was obtained from each patient at this step. The Leeds Assessment of Neuropathic Symptoms and Signs (LANSS) pain scale was also used to evaluate neuropathic components of chronic pain (Table 1). In the LANSS scale, $\geq 12$ points indicate neuropathic pain, while $<12$ points indicate nociceptive pain.

The study protocol was approved by the local Ethics Committee (No. 2017-167). The study was conducted in accordance with the principles of the Declaration of Helsinki.

\section{Statistical analysis}

Statistical analysis was performed using the IBM SPSS version 22.0 software (IBM Corp., Armonk, NY, USA). Descriptive data were expressed in mean and standard deviation (SD), median (min.-max.) values, number ( $\mathrm{n}$ ), and frequency (\%). The KolmogorovSmirnov test was used to analyze the normality of data distribution. Independent sample t-test and Mann-Whitney $\mathrm{U}$ test were used to analyze quantitative independent data. The chi-square test was used to analyze qualitative independent data. A p value of 0.05 was considered statistically significant.

\section{Results}

Of 80 patients included in the study, 1 patient in Group 1 (epidural analgesia group) withdrew her consent and additional three patients were lost to follow-up at 6 months. In Group 2, two patients were lost to follow-up at 6 months. A total of 74 patients were enrolled (Group 1, n=31 and Group 2, $n=43$ ) (Fig. 1).

There was no significant difference in the age, BMI, major comorbidities (diabetes mellitus, asthma, hyper-/hypothyroidism, hypertension, heart disease), operative procedures, total operative time, estimated blood loss, need for transfusion, complications and radiation therapy/chemotherapy applied ( $p>0.05$ ). However, the number of patients on depression treatment was higher in Group 2 than Group 1 $(p<0.05)$. Demographic and clinical characteristics of the patients are shown in Table 2 and Table 3.

The VAS scores at $24 \mathrm{~h}$ were lower in Group 1 than Group 2 (3.29 vs 3.93; $p<0.05$ ). However, the VAS scores at 6 months were 2.03 in Group 1 and 2.53 in Group 2, indicating no statistically significant difference ( $p>0.05)$. At 6 months, there was no significant difference in the LANSS scores including both five subdomains and allodynia and hyperalgesia between the groups ( $p>0.05$ ). None of the patients received $\geq 12$ points from the LANSS scale (Table 4 ).

\section{Discussion}

Over 200 million major surgeries have been performed annually worldwide. ${ }^{[14]}$ However, postoperative pain is still a major problem in $85 \%$ of patients. ${ }^{[15]}$ Although the World Health Organization recognizes relief and prevention of pain as a human right and many novel therapeutic agents and procedures have been developed in recent years, there is still unmet needs for postoperative pain. ${ }^{[16,}$ ${ }^{17]}$ The main goal of pain management can prevent adverse events including tachycardia, hypertension, myocardial ischemia, alveolar ventilation, and poor wound healing. ${ }^{[18]}$ In addition, chronicity of postoperative pain can be eliminated. ${ }^{[6]}$ Chronic postoperative pain is defined as surgery-related pain persisting for more than expected for wound healing ranging from three to six months, and minimum three months are often required. ${ }^{[19]}$ Pain must be located in the incision site or referred pain site, and it must not be experienced before surgery or it must show different characteristics and severity, if present. ${ }^{[19]}$ Considering prolonged duration of chronic postoperative pain and related morbidities, it is accepted as a major complication of surgery. ${ }^{[2]}$ 
Table 1. The Leeds Assessment of Neuropathic Symptoms and Signs (LANSS) Pain Scale

\section{The Leeds Assessment of Neuropathic Symptoms and Signs (LANSS) Pain Scale}

This pain scale can help to determine whether the nerves that are carrying your pain signals are working normally or not. It is important to find this out in case different treatments are needed to control your pain.

A. PAIN QUESTIONNAIRE

- Think about how your pain has felt over the last week.

- Please say whether any of the descriptions match your pain exactly.

1. Does your pain feel like strange, unpleasant sensations in your skin? Words like pricking, tingling, pins and needles might describe these sensations

a) NO - My pain doesn't really feel like this

b) YES - I get these sensations quite a lot

2. Does your pain make the skin in the painful area look different from normal? Words like mottled or looking more red or pink might describe the appearance.

a) NO - My pain doesn't affect the color of my skin

b) YES - I've noticed that the pain does make my skin look different from normal

3. Does your pain make the affected skin abnormally sensitive to touch? Getting unpleasant sensations when lightly stroking the skin, or getting pain when wearing tight clothes might describe the abnormal sensitivity.

a) NO - My pain doesn't make my skin abnormally sensitive in that area

b) YES - My skin seems abnormally sensitive to touch in that area

4. Does your pain come on suddenly and in bursts for no apparent reason when you're still? Words like electric shocks, jumping and bursting describe these sensations.

a) NO - My pain doesn't really feel like this

b) YES - I get these sensations quite a lot

5. Does your pain feel as if the skin temperature in the painful area has changed abnormally? Words like hot and burning describe these sensations.

a) $\mathrm{NO}$ - I don't really get these sensations

b) YES - I get these sensations quite a lot

\section{B. SENSORY TESTING}

Skin sensitivity can be examined by comparing the painful area with a contralateral or adjacent non-painful area for the presence of allodynia and an altered pin-prick threshold (PPT).

1. Allodynia. Examine the response to lightly stroking cotton wool across the non-painful area and then the painful area. If normal sensations are experienced in the non-painful site, but pain or unpleasant sensations (tingling, nausea) are experienced in the painful area when stroking, allodynia is present.

a) NO - Normal sensations in both areas

b) YES - Allodynia in painful area only

2. Altered pin-prick threshold

Determine the pin-prick threshold by comparing the response to a 23-gauge (blue) needle mounted inside a $2 \mathrm{ml}$ syringe barrel placed gently onto the skin in a non-painful and then painful areas.

If a sharp pin prick is felt in the non-painful area, but a different sensation is experienced in the painful area, eg. none/ blunt only (raised PPT) or a very painful sensation (lowered PPT), an altered PPT is present.

If a pinprick is not felt in either area, mount the syringe onto the needle to increase the weight and repeat.

a) NO - Equal sensation in both areas

b) YES - Altered PPT in painful area

SCORING: Add values in parentheses for sensory description and examination findings to obtain overall score.

TOTAL SCORE (maximum 24):

If score $<12$, neuropathic mechanisms are unlikely to be contributing to the patient's pain.

If score $\geq 12$, neuropathic mechanisms are likely to be contributing to the patient's pain. 


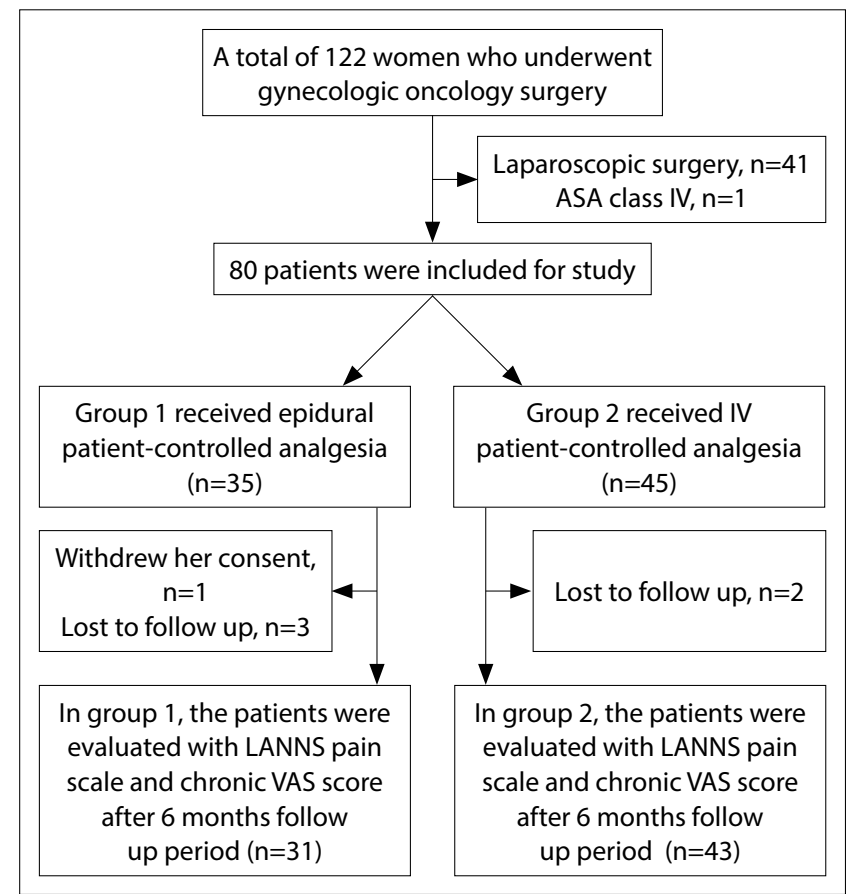

Figure 1. Study flowchart.

Table 2. Demographic characteristics and medical history of patient groups

\begin{tabular}{|c|c|c|c|c|c|}
\hline \multirow[t]{2}{*}{ Variables } & \multicolumn{2}{|c|}{$\begin{array}{l}\text { Epidural } \\
\text { PCA }\end{array}$} & \multicolumn{2}{|c|}{$\begin{array}{c}\text { IV } \\
\text { PCA }\end{array}$} & \multirow[t]{2}{*}{$\mathbf{p}$} \\
\hline & $\mathbf{n}$ & $\%$ & $\mathbf{n}$ & $\%$ & \\
\hline Age, $y$, mean $\pm S D$ & \multicolumn{2}{|c|}{$57.3 \pm 10.1$} & \multicolumn{2}{|c|}{$52.5 \pm 10.9$} & $0.06^{a}$ \\
\hline $\mathrm{BMI}, \mathrm{kg} / \mathrm{m}^{2}$, mean $\pm \mathrm{SD}$ & \multicolumn{2}{|c|}{$33.9 \pm 5.2$} & \multicolumn{2}{|c|}{$34.2 \pm 6.9$} & $0.86^{a}$ \\
\hline \multicolumn{6}{|l|}{ Comorbidities } \\
\hline Diabetes mellitus & 4 & 12.9 & 10 & 23.3 & $0.26^{b}$ \\
\hline Hypertension & 11 & 35.5 & 10 & 23.3 & $0.25^{b}$ \\
\hline Asthma & 1 & 3.2 & 0 & 0 & $0.24^{b}$ \\
\hline Hypo/hyperthyroidi & 3 & 9.7 & 7 & 16.3 & $0.41^{b}$ \\
\hline Depression treatment & 0 & 0 & 6 & 14 & $0.03^{b}$ \\
\hline Adjuvant chemotherapy & 16 & 51.6 & 18 & 41.9 & $0.41^{b}$ \\
\hline Adjuvant radiotherapy & 8 & 25.8 & 10 & 23.3 & $0.8^{\mathrm{b}}$ \\
\hline
\end{tabular}

PCA: Patient controlled analgesia; y: Years; BMI: Body mass index: SD: Standard deviation; a: Independent sample T test; b: Chi-square test.

There are many risk factors for the chronicity of postoperative pain including type and duration of surgery, female sex, young adulthood, genetic susceptibility, psychosocial factors, existing chronic pain before surgery, and duration and severity of acute postoperative pain. ${ }^{[21]}$ Among these factors, the latter one, acute postoperative pain, is the major modifiable and preventable factor, as severe acute pain causes central sensitization and reduces pain threshold against painful stimuli, thereby, leading
Table 3. Surgical and pathological findings of patient groups

\begin{tabular}{lllll}
\hline Variables & $\begin{array}{c}\text { Epidural } \\
\text { PCA }\end{array}$ & & \multicolumn{1}{c}{ IV } & PCA \\
\cline { 2 - 2 } & n $\%$ & n $\%$ \\
\hline
\end{tabular}

Total operative time,

$\min$, mean $\pm S D$

$329 \pm 61.3 \quad 330 \pm 64.1 \quad 0.93^{c}$

$\mathrm{EBL}, \mathrm{ml}$, mean $\pm \mathrm{SD}$

$555 \pm 412.4 \quad 538 \pm 365.5 \quad 0.66^{c}$

Transfusion need

$\begin{array}{lllll}8 & 25.8 & 11 & 25.6 & 0.98^{\mathrm{b}}\end{array}$

Primary carcinoma $0.85^{\mathrm{b}}$

\begin{tabular}{|c|c|c|}
\hline Endometrial cancer & $21 \quad 67.7$ & 69.8 \\
\hline Endometrioid & 12 & 26 \\
\hline Serous & 4 & 1 \\
\hline Mixt & 1 & 2 \\
\hline Carcinosarcoma & 1 & 1 \\
\hline Clear cell & 2 & 0 \\
\hline SCC & 1 & 0 \\
\hline
\end{tabular}

$\begin{array}{lllll}\text { Ovarian cancer } \quad 10 & 32.3 & 13 & 30.2\end{array}$

Serous papillary $6 \quad 9$

Endometrioid $\quad 3 \quad 1$

Musinous $\quad 0 \quad 2$

$\begin{array}{lll}\text { Clear cell } & 1 & 0\end{array}$

Yolk sac $\quad 0 \quad 1$

Surgical procedure $\quad 0.36^{\mathrm{b}}$

$\begin{array}{lccccc}\text { Staging surgery } & 20 & 64.5 & 32 & 74.4 & \\ \text { PDS } & 11 & 35.5 & 11 & 25.6 & \\ \text { Complications } & & & & & \\ \quad \text { DVT } & 1 & 3.2 & 1 & 2.3 & 0.81^{\mathrm{b}} \\ \quad \text { Infection } & 2 & 6.5 & 2 & 4.7 & 0.74^{\mathrm{b}} \\ \quad \text { Ileus } & 1 & 3.2 & 2 & 4.7 & 0.76^{\mathrm{b}} \\ \text { UTI } & 0 & 0 & 1 & 2.3 & 0.39^{\mathrm{b}}\end{array}$

Min: Minute; SD: Standard deviation; PDS: Primary debulking surgery; DVT: Deep vein trombosis; UTI: Urinary tract infection; b: Chi-square test; c: Mann-Whitney $\mathrm{U}$ test.

Table 4. Pain scores of patient groups

\begin{tabular}{lccc}
\hline Variables & $\begin{array}{c}\text { Epidural } \\
\text { PCA } \\
\text { Mean } \pm \text { SD }\end{array}$ & $\begin{array}{c}\text { IV } \\
\text { PCA } \\
\text { Mean } \pm \text { SD }\end{array}$ & p \\
\hline Acute VAS score & $3.29 \pm 1.37$ & $3.93 \pm 1.32$ & $\mathbf{0 . 0 3 6}^{c}$ \\
Chronic VAS score & $2.03 \pm 1.64$ & $2.53 \pm 1.75$ & $0.21^{c}$ \\
LANNS score & $1.10 \pm 2.47$ & $0.79 \pm 2.13$ & $0.52^{c}$ \\
\hline
\end{tabular}

PCA: Patient controlled analgesia; VAS: Visual analog scale; LANSS: The Leeds Assessment of Neuropathic Symptoms and Signs; c: Mann-

Whitney $\mathrm{U}$ test.

to exacerbation of the response and chronicity of pain eventually. ${ }^{[22,23]}$ 
Multimodal and preemptive analgesia are modalities for the prevention and relief of postoperative pain, and, thereby minimizing the risk for chronic postoperative pain. In a study using preemptive analgesia, even single-dose ibuprofen before septorhinoplasty decreased postoperative pain and the amount of opioids used by more than $50 \% .{ }^{[24]}$ More important$l y$, it is critical to administer the analgesic agent or intervention before peripheral and central sensitization and pain development. Accordingly, in addition to analgesic agents, regional anesthesia seems to be effective. In a Cochrane review, epidural anesthesia and paravertebral block reduced the risk for chronic postoperative pain in patients undergoing thoracotomy and breast surgery, although the authors concluded that these results could not be generalized due to limited data for other types of surgeries. ${ }^{[25]}$

Long et al. ${ }^{[26]}$ showed that preemptive analgesia was effective in patients undergoing minimal invasive gynecological surgeries, and that regional blockade (i.e., paracervical block, transversus abdominis plane block, and pudendal block) was the most effective method based on risk-benefit analysis. Although ketamine, anticonvulsants, and dexmedetomidine are effective for preemptive analgesia, possible side effects limit their use. In addition, dexamethasone, acetaminophen, and non-steroidal anti-inflammatory drugs have been also shown to be moderately effective. In the present study, all patients received preemptive analgesia with tramadol $100 \mathrm{mg}$ and paracetamol $1000 \mathrm{mg}$ before surgery, followed by intraoperative remifentanil and opioid analgesia. In addition, Group 1 received neuroaxial patient-controlled analgesia with bupivacaine and fentanyl via an epidural catheter, while Group 2 received IV patient-controlled analgesia with tramadol infusion. In the acute postoperative period, all patients in both groups achieved adequate analgesia. However, the VAS scores at $24 \mathrm{~h}$ were lower in Group 1, although there was no significant difference in the VAS and LANSS scores at 6 months between the groups.

In their study, Brandsborg et al. ${ }^{[6]}$ found that 31.9\% of the patients who underwent hysterectomy experienced chronic pain at 1 year following surgery. In the aforementioned study, preoperative pelvic pain (odds ratio [OR]: 3.25), previous cesarean section (OR: 1.54), surgery due to existing pain (OR: 2.98), and chronic pain in another site of the body (OR: 3.19) were found to be main risk factors for chronic pain. In addition, the authors showed that vaginal hysterectomy posed less risk than abdominal hysterectomy for the development of chronic pain. However, the authors found no correlation between the incision type used in abdominal hysterectomy and chronic progression of postoperative pain. Interestingly, in the aforementioned study, epidural anesthesia did not reduce the risk for chronic pain and spinal anesthesia reduced the chronicity of pain. In another study, Saxena et al. ${ }^{[27]}$ found that $38 \%$ of patients who underwent laparotomy for ovarian cancer staging experienced persistent chronic postoperative pain at 3 months and suggested that the early postoperative VAS scores were the strongest predictors of chronic postoperative pain.

The first step of an effective pain management plan is defining pain type in patients with chronic pain. ${ }^{[5]}$ About $40 \%$ of cancer patients experience neuropathic pain, which increases the severity of pain and the amount of analgesics used, and, thereby impairing the quality of life. ${ }^{[28-30]}$ For these patients, anticonvulsants or antidepressants must be added to the treatment, leading to modification of the treatment plan. On the other hand, diagnosing neuropathic pain is quite challenging. Although several scales are in use, in their meta-analysis, Mulvey et al. ${ }^{[31]}$ have demonstrated that the LANSS scale is the most sensitive tool for identifying neuropathic pain. In the present study, consistent with the literature, we also used the LANSS scale to evaluate neuropathic pain. However, none of the patients received $\geq 12$ points from the LANSS scale. Our finding indicating that none of the patients experienced neuropathic pain at 6 months is, however, inconsistent with the previous findings. Appropriate preemptive and multimodal analgesia may possibly prevent chronicity of postoperative pain. However, the reason for the lack of patients with neuropathic pain, which may be associated with the disease itself or radiation therapy/ chemotherapy applied, can be explained by small sample size of the present study and $\sim 70 \%$ sensitivity of the scale we used. ${ }^{[32]}$

\section{Limitations}

First, our sample size is small. Second, there is no control group in the present study, as in our routine 
clinical practice, we use preemptive analgesia preoperatively, followed by patient-controlled analgesia postoperatively. Third, we were unable to conduct a more detail follow-up schedule for the evaluation of postoperative pain. Finally, there is a limited number of studies investigating the effect of cancer surgery on chronic postoperative pain development in patients with a gynecological malignancy and, therefore, further large-scale, long-term scale are needed to gain a better understanding on how to minimize the risk for chronic postoperative pain.

\section{Conclusion}

Our study results show that epidural patient-controlled analgesia and IV patient-controlled analgesia with tramadol have similar effects for the chronicity of pain in patients undergoing surgery for gynecological malignancy, although better outcomes can be achieved with epidural analgesia in the acute stage. We recommend further, comparative studies using preemptive and multimodal analgesia combining with different techniques to shed light into optimal anesthesia.

Acknowledgement: The authors would like to thank Ertan Çınar for his proofreading the manuscript.

Ethics Committee Approval: The study protocol was approved by Bakırköy Dr. Sadi Konuk Training and Research Hospital Clinical Research Ethics Committee (date: 17.07. 2017, number: 2017-07-02). The study was conducted in accordance with the principles of the Declaration of Helsinki.

\section{Conflict-of-interest issues regarding the authorship or article: None declared.}

Peer-rewiew: Externally peer-reviewed.

\section{References}

1. Noone AM, Howlader N, Krapcho M, Miller D, Brest A, Yu M, et al. SEER cancer statistics review, 1975-2012. Accessed 2015, from https://seer.cancer.gov/archive/ csr/1975_2015/\#contents.

2. Ferguson SE, Panzarella T, Lau S, Gien LT, Samouëlian V, Giede $C$, et al. Prospective cohort study comparing quality of life and sexual health outcomes between women undergoing robotic, laparoscopic and open surgery for endometrial cancer. Gynecol Oncol 2018;149(3):476-83. [CrossRef]

3. Fanning J, Yacoub E, Hojat R. Laparoscopic-assisted cytoreduction for primary advanced ovarian cancer: success, morbidity and survival. Gynecol Oncol 2011;123(1):47-9.

4. Abitbol J, Cohn R, Hunter S, Rombaldi M, Cohen E, Kes- sous $\mathrm{R}$, et al. Minimizing pain medication use and its associated costs following robotic surgery. Gynecol Oncol 2017;144(1):187-92. [CrossRef]

5. Macrae WA. Chronic pain after surgery. Br J Anaesth 2001;87(1):88-98. [CrossRef]

6. Brandsborg B, Nikolajsen L, Hansen CT, Kehlet $H$, Jensen TS. Risk factors for chronic pain after hysterectomy: a nationwide questionnaire and database study. Anesthesiology 2007;106(5):1003-12. [CrossRef]

7. Radresa O, Chauny JM, Lavigne G, Piette E, Paquet J, Daoust R. Current views on acute to chronic pain transition in post-traumatic patients: risk factors and potential for pre-emptive treatments. J Trauma Acute Care Surg 2014;76(4):1142-50. [CrossRef]

8. Kaye AD, Helander EM, Vadivelu N, Lumermann L, Suchy T, Rose M, et al. Consensus Statement for Clinical Pathway Development for Perioperative Pain Management and Care Transitions. Pain Ther 2017;6(2):129-41. [CrossRef]

9. Luo ZD, Chaplan SR, Higuera ES, Sorkin LS, Stauderman KA, Williams $M E$, et al. Upregulation of dorsal root ganglion (alpha)2(delta) calcium channel subunit and its correlation with allodynia in spinal nerve-injured rats. J Neurosci 2001;21(6):1868-75. [CrossRef]

10. Munro A, Sjaus A, George RB. Anesthesia and analgesia for gynecological surgery. Curr Opin Anaesthesiol 2018;31(3):274-9. [CrossRef]

11. Chen LM, Weinberg VK, Chen C, Powell CB, Chen LL, Chan $\mathrm{JK}$, et al. Perioperative outcomes comparing patient controlled epidural versus intravenous analgesia in gynecologic oncology surgery. Gynecol Oncol 2009;115(3):35761. [CrossRef]

12. de Leon-Casasola OA, Karabella D, Lema MJ. Bowel function recovery after radical hysterectomies: thoracic epidural bupivacaine-morphine versus intravenous patientcontrolled analgesia with morphine: a pilot study. J Clin Anesth 1996;8(2):87-92. [CrossRef]

13. Moslemi F, Rasooli S, Baybordi A, Golzari SE. A Comparison of Patient Controlled Epidural Analgesia With Intravenous Patient Controlled Analgesia for Postoperative Pain Management After Major Gynecologic Oncologic Surgeries: A Randomized Controlled Clinical Trial. Anesth Pain Med 2015;5(5):e29540.0 [CrossRef]

14. Weiser TG, Regenbogen SE, Thompson KD, Haynes AB, Lipsitz SR, Berry WR, et al. An estimation of the global volume of surgery: a modelling strategy based on available data. Lancet 2008;372(9633):139-44. [CrossRef]

15. Gan TJ, Habib AS, Miller TE, White W, Apfelbaum JL. Incidence, patient satisfaction, and perceptions of post-surgical pain: results from a US national survey. Curr Med Res Opin 2014;30(1):149-60. [CrossRef]

16. Brennan F, Carr DB, Cousins M. Pain management: a fundamental human right. Anesth Analg 2007;105(1):205-21.

17. Pyati S, Gan TJ. Perioperative pain management. CNS Drugs 2007;21(3):185-211. [CrossRef]

18. Vadivelu N, Mitra S, Narayan D. Recent advances in postoperative pain management. Yale J Biol Med 2010;83(1):1125. 
19. Treede RD, Rief W, Barke A, Aziz Q, Bennett MI, Benoliel $R$, et al. A classification of chronic pain for ICD-11. Pain 2015;156(6):1003-7. [CrossRef]

20. Macrae WA. Chronic post-surgical pain: 10 years on. $\mathrm{Br} \mathrm{J}$ Anaesth 2008;101(1):77-86. [CrossRef]

21. Thapa P, Euasobhon P. Chronic postsurgical pain: current evidence for prevention and management. Korean J Pain 2018;31(3):155-173. [CrossRef]

22. Bruce J, Quinlan J. Chronic Post Surgical Pain. Rev Pain 2011;5(3):23-9. [CrossRef]

23. Kehlet $H$, Jensen TS, Woolf $C J$. Persistent postsurgical pain: risk factors and prevention. Lancet 2006;367(9522):161825. [CrossRef]

24. Gozeler MS, Sakat MS, Kilic K, Ozmen O, Can A, Ince I. Does a single-dose preemptive intravenous ibuprofen have an effect on postoperative pain relief after septorhinoplasty? Am J Otolaryngol 2018;39(6):726-30. [CrossRef]

25. Andreae MH, Andreae DA. Regional anaesthesia to prevent chronic pain after surgery: a Cochrane systematic review and meta-analysis. Br J Anaesth 2013;111(5):711-20.

26. Long JB, Bevil K, Giles DL. Preemptive Analgesia in Minimally Invasive Gynecologic Surgery. J Minim Invasive Gynecol 2019;26(2):198-218. [CrossRef]

27. Saxena AK, Chilkoti GT, Chopra AK, Banerjee BD, Sharma
T. Chronic persistent post-surgical pain following staging laparotomy for carcinoma of ovary and its relationship to signal transduction genes. Korean J Pain 2016;29(4):23948. [CrossRef]

28. Bennett MI, Rayment C, Hjermstad M, Aass N, Caraceni A, Kaasa $S$. Prevalence and aetiology of neuropathic pain in cancer patients: a systematic review. Pain 2012;153(2):35965. [CrossRef]

29. Fainsinger RL, Nekolaichuk C, Lawlor $P$, Hagen N, Bercovitch $M$, Fisch $M$, et al. An international multicentre validation study of a pain classification system for cancer patients. Eur J Cancer 2010;46(16):2896-904. [CrossRef]

30. Garzón-Rodríguez C, Lyras L, Gayoso LO, Sepúlveda JM, Samantas E, Pelzer U, et al. Cancer-related neuropathic pain in out-patient oncology clinics: a European survey. BMC Palliat Care 2013;12(1):41. [CrossRef]

31. Mulvey MR, Boland EG, Bouhassira D, Freynhagen R, Hardy J, Hjermstad MJ, et al. Neuropathic pain in cancer: systematic review, performance of screening tools and analysis of symptom profiles. Br J Anaesth 2017;119(4):765-74. [CrossRef]

32. Unal-Cevik I, Sarioglu-Ay S, Evcik D. A comparison of the DN4 and LANSS questionnaires in the assessment of neuropathic pain: validity and reliability of the Turkish version of DN4. J Pain 2010;11(11):1129-35. [CrossRef] 